\title{
石油精製・輸送モデルの開発による日韓石油産業の 連携オプションの分析
}

曾 我 正 美*

\section{Analysis of the Japanese-Korean Tie-up Option by the Development of Petroleum Refinery and Transportation System Model}

Masayoshi SOGA

\begin{abstract}
Recently there is an important trial to increase the economical potential especially in North America and EU with international cooperation. In Far Eastern area there are some opinions that it is essential for Far Eastern economy to establish the first economic free zone including China, Korea and Japan, too.

So in this paper the economical evaluation is tried for the efficiency that will be enhanced by Japanese-Korean Tie-up Option on the petroleum industry as a first step. The petroleum refinery and transportation system model is developed with linear programming method. Using this model, it is discovered that some Japanese-Korean Tie-up Option will be able to get higher efficiency economically equivalent for $300 \sim 400$ million US $\$$ a year compared with non-Tie-up condition.

For this improved condition, the quantity of petroleum transportation will have to be increased to $30 \sim 38$ million KL between Japanese and Korean, too. This amount is $2.7 \sim 3.5$ times as large as the amount in 1997.

So it should be understood very well that the good availability of tankers for this transportation in this area would be necessary for the efficient economic condition in future.
\end{abstract}

\section{1.はじめに}

日本および韓国における貨物輸送量(トンキロベース) 全体に占める内航海運活用割合は世界主要国にお いて最も高い水準にある。石油製品輸送量においても日本に付いて更に高い割合で、主要な輸送手段とな っている(1)。

近年石油産業が自由化され物流効率化等を含め合理化が急進展し、複数石油会社の戦略提携による油槽 所の統廃合および製油所からの中距離ローリー輸送量が増加等する中で内航タンカー船腹の余剩も懸念さ れている(2)。一方、世界においては北米自由貿易協定および欧州連合等の進展による国家を超えた経済合理 化過程にあり ${ }^{(2)}$ 、東アジアにおいても日韓中 3 国の経済圈形成が重要である ${ }^{(3)}$ との見解も出されている。本 稿では、日韓石油産業の世界的規模と将来的自由化について着目し今後の効率化可能性に付いて定量的試 算を行う事とした。試算に当たっては日韓の石油精製・輸送モデルを開発し日韓石油産業の連携オプショ ンの効果に付いて分析した。

効率化検討の結果、連携オプションの経済効果は年間 $3 \sim 4$ 億米 \$程度となる場合もあり、物流面にお

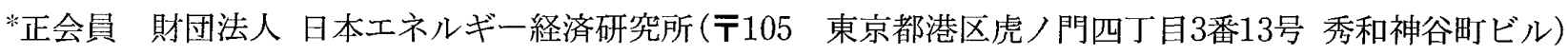


ける日韓間の石油輸出入量は大幅に増加し 30〜38百万KL (1997年の2.7〜3.5倍) となった。今後の日韓地域 における石油産業の効率化検討のためには日韓石油タンカー輸送能力の将来に付いてのより詳細な検討が 必要であることも分かった。

\section{2.アジア石油市場の将来展開}

アジアの石油市場は、80年代後半からの経済発展によって本格的な成長が始まり、90年代半ばには石油 需要、原油処理、原油・製品貿易に付いて 80 年代初頭に比べて 2 倍程度へ増加するなど域内石油市場規模 が大きく拡大した。石油需要規模は 90 年の 1,300 万B/Dから 97 年には 1,800 万B/D (約 $44 \%$ 増加)まで増加し 欧州と同程度となった。このようなアジア石油需要の増加は90年代初頭に停滞した世界の他地域の石油需 要をカバーする形となり、アジアでの石油需要の増加がそのまま当該期間の世界石油需要の増加となった。

この間石油需要の急增と製油所の活発な建設によってアジアの原油必要量は大幅に増加し、中東を中心 に原油輸入が拡大した。域内原油生産の増加が鈍化し、アジアの中東原油依存度は近年まで徐々に増大し 96年には90\%に達した。このようにアジア石油市場 の中東依存は著しく高まっており、90年代に入って 欧州、米国向けに比べると中東産原油のアジア向け 価格に相対的な割高感が生じている(図 1 )。特に 1997年は価格差が 1 バーレル (159リットル)当り 3 ドル程度まで広がった。原油価格はLNG・石炭など 他のエネルギー源の価格決定にも非常に大きく影響 していることを考えると、原油価格の相対的な割高 感は単に石油産業だけの問題ではない。因みにこの 3 ドル格差にアジアの石油需要量を乗ずると年間90 億 \$程度となるが、イラク危機の時に日本が支払っ た軍事費用 60 億 \$を超える規模となっている。

1997年半ばに起こったアジアの通貨危機は一時的 な石油需要の減退をもたらし、一方製油所の建設投 資計画に長期の停滞をきたしつつある。2000年以降 で回復が予想される石油需要に対して精製能力の整 備が追いつかず、中国、アセアンなど域内に抒ける 石油需給ギヤップが拡大する可能性が高い。この需 給ギャップを埋めることができる選択肢として考え られるのは、(1)域内・域外からの既存製油所の余力 を利用した製品輸入の拡大、(2)国内参入条件の整備 に基づく外資導入による製油所の新・増設である。 2000年以降の石油需要増大に対して、既存製油所に 余力を持つ韓国と日本にとっては、その供給を行う 大きなチャンスが訪れる可能性がある。

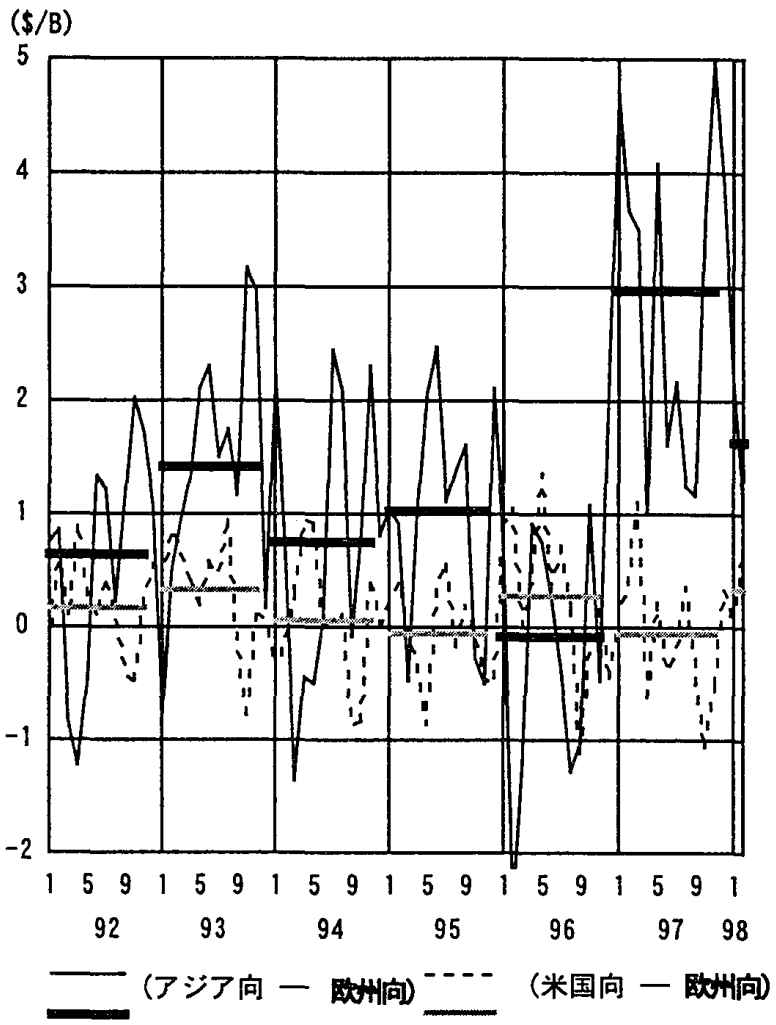

図 1 アラビアンライト原油の向け先別フォーミ ユラ価格の推移

（出所）PIWのデー夕に基づいて日本エネルギー経済研究所 が作成

\section{3、日韓提携オプション検討の必要性}

\section{1 韓国の石油産業が直面している課題}

通貨危機の影響による主な石油産業の変化を整理すると、(1)石油製品需要の減少 (98年の 1 ～月の韓国 の石油需要は 97 年同期対比 $16 \%$ 程度減少している。） (2)製油所稼働率の下落 (3)石油会社の収益力および 資金力の悪化等が挙げられる。この結果、(1)製油所設備投資の延期および取り消し (2)石油産業の規制緩 和スケジュールの短縮 (エネルギー安定供給から外国資本投資の誘致とエネルギー効率の追求へと、韓国政 府が基本方針を変更）（3外国資本による既存の石油会社の買収および資本参加が積極的に行われつつある。 
韓国の製油所は、96年に大規模な原油処理装置 の新設を実施した。今後10年間、大きな輸出能力 を保持することとなる。設備面の強みと弱みを見 ると、最も強みを発揮しているのは、原油処理装 置の規模である(図 2)。すなわち、SKは 1 つの製 油所の規模が 80 万 $\mathrm{B} / \mathrm{D}$ 以上で世界で最も大きい。 一番小さいHannHwaも28万B/Dの規模で日本や シンガポールの最大規模の製油所よりさらに大き い。また、原油処理装置 1 基当たりの規模も日本 に比べて相当大きく、日本の製油所の 1 基当たり 平均 10 万 $\mathrm{B} / \mathrm{D} の 1.5$ 倍になっている。

原油処理装置能力の圧倒的な強さに比べると、 2 次設備はそれほど充実しておらず、ガソリン、 灯・軽油に付いては国内需要を満たす程度のもの になっている(図 3 )。2 次設備の中で最も弱い部 門は重油に対する脱硫設備であり、現在の脱硫設 備だけでは内需の $50 \%$ 程度を満たすこともできな い。毎年低硫黄原油の処理あるいは低硫黄重油の 輸入によって必要な需要を満たしている。この点 が日本と大きく異なっている。今後LG-Caltexの 7 万 $\mathrm{B} / \mathrm{D}$ の重脱硫設備の新設が計画されている が、通貨危機の影響で他の脱硫設備の新・増設は 考えにくい。さらに2000年代初頭の重油規制強化 が予定通りに実施されると、硫黄分 $0.5 \%$ 以下の重 油が需要の $70 \%$ 以上になり、韓国の低硫黄重油の 不足は深刻な状況になる可能性が高い。

トッパー能力で見たように、韓国の製油所規模 は大きいので、オフサイト能力をみた場合にも製 品輸出関連設備の能力が高いことがわかる。製品 タンクは内需対比30日程度で日本よりかなり高い 能力を持っている。このことは製品輸出に有利な 条件を韓国の製油所が整えていることを示す。

韓国最大級の製油所で港湾能力をみると、原油 用には30万トン以上の船が着ける栈橋が 2 基あ り、製品用には最大 15 万トンの栈橋を 1 基、 7 万 トンの栈橋を 2 基持っている(表 1 )。製品用栈橋 の規模が大きいことは韓国の製油所からの製品輸 出の大きな力となっている。一方、日本で最大級 の製油所の栈橋規模をみると、原油処理用はトッ

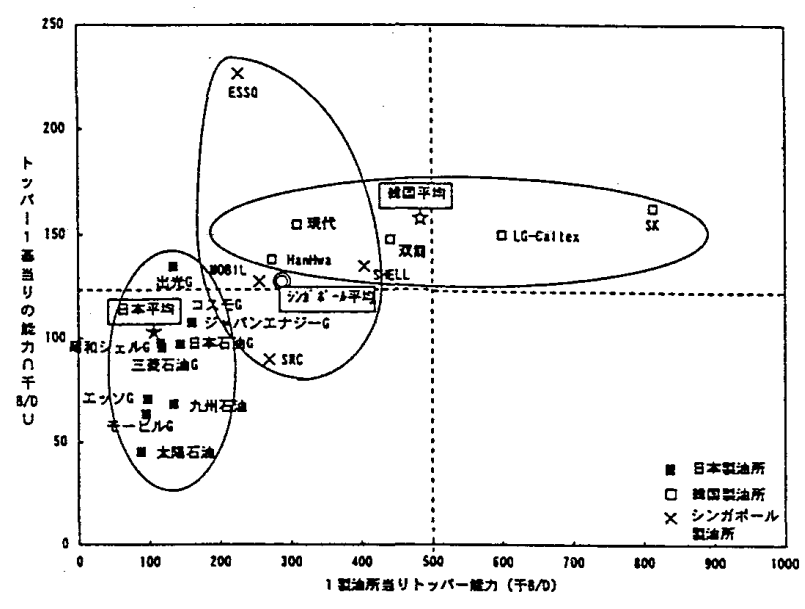

図 2 韓国等の原油処理設備能力

出所 : 韓国、日本、シンガポールの各種資料に基づいてエネ 研が作成

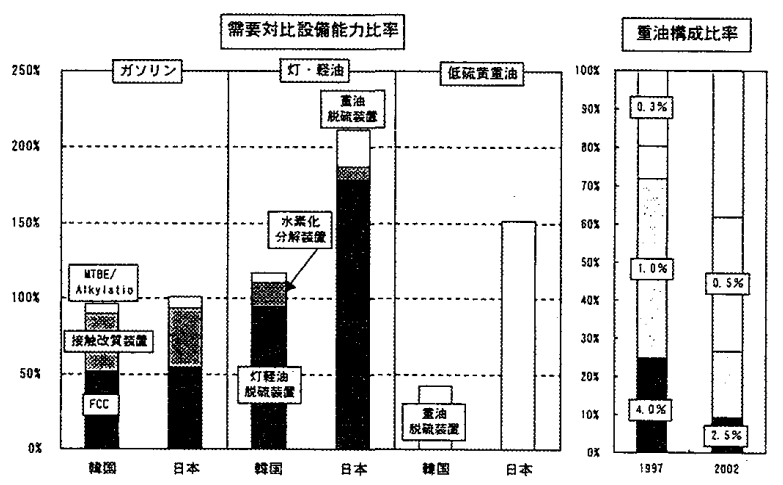

図 3 韓国の 2 次処理設備能力および硫黄分別重油 構成比率の変化

注：需要対比設備能力＝製品需要 $/($ 設備Capacity $\times$ 製品得率 $)$ 出所：石油資料など日韓の各種データに基づいてエネ研が作成

表 1 韓国等のオフサイト設備能力 出所：該当製油所の資料

\begin{tabular}{|c|c|c|c|}
\hline & 国年 & 旦本 B些 \\
\hline \multirow[t]{3}{*}{ 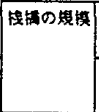 } & 洜油 & x 33 万トン × 1 菜 & x 26 万トン $\times 13$ \\
\hline & & x 30万トン × 1 & Sx 13 万トン X 1X \\
\hline & 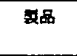 & 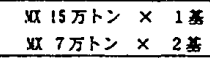 & 女x 8ภトン $\times 1 \mathrm{x}$ \\
\hline 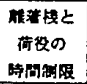 & 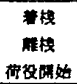 & 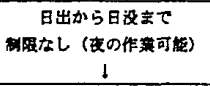 & $\begin{array}{c}\text { 日出から日没まて } \\
\downarrow \\
\downarrow\end{array}$ \\
\hline
\end{tabular}
パー規模に比べて遜色ないが、製品用は 8 万トンの栈橋が 1 基しかない。これは、一般的な輸出船の規模 である 5 万トン級の船が日本の製油所では同時に 1 隻しか着けないのに対して、韓国の製油所では 3 隻が 同時に着けることを意味している。また、韓国では離栈と荷役に対する時間制約がなくて、夜間でもこの作 業を実施できることも強みである。このような韓国の製油所の栈橋規模と使用時間の融通性をみると、韓国 の製油所がトッパーの大きさと同時に製品輸出に関して大きな設備メリットを持っていることがわかる。

韓国は、トッパーとオフサイトの両面で製品輸出に関して規模の経済性を十分に発揮できる設備能力を 持っている一方、脱硫設備の不足が今後の大きな課題になっている。大きな資金負担をできるだけ持たな いで、2000年以降の重油硫黄分の規制強化に韓国がいかに対応していくかが極めて重要である。 


\section{2 日本の石油産業が直面している課題}

1996年 3 月末の特定石油製品輸入㟻定措置法 (特石法) 廃止で石油製品輸入が自由化されたた め、わが国の国内石油市場では競争が激化した。 最近の国内石油製品価格は、国際価格水準(輸入製 品の水準)と比べてあまり格差がない状況となっ ている。石油連盟資料によると1993年時点で3,701 億円あった石油産業の経常利益は、1997年時点で は621億円となり、売上高経常利益率も0.5\%を下 回る水準へ低下した(図 4)。

石油産業にとって製油所の設備稼働を上昇させ 固定費負担を軽減することは、コスト削減オプシ ヨンの1つとして重要である。石油製品の輸出は、 製油所の稼働を上昇させるための有力な手段であ る。韓国ほどに石油製品輸出が大きな重みを持っ ていないが、わが国でも1989年頃から徐々に石油 製品輸出が拡大してきた(図 5 )。

特石法の廃止と対応する形で、1997年 7 月には 石油製品輸出の自由化が実施された。韓国からわ が国へのナフサ輸出を除くと、韓国とわが国相互 間の石油製品貿易は、まだそれほど大規模なもの になっていないのが現状である(図6)。

わが国の石油産業の弱みの 1 つは、韓国やシン ガポールなどと比較した場合に、精製コストが相 対的に割高となっていることである(図 7 )。特に 固定費を含んでみる場合は、白油化、環境規制、 安全規制などに対応したわが国固有のコストが含 まれているので、割高となる。アジアにおける石 油製品輸出活動は、シンガポール市場で形成され る精製マージンを指標として、マージナルな変動 費十 $\alpha$ のベースで行われる。変動費ベースでもわ が国の精製コストは韓国やシンガポールと比ベて 多少割高であるが、変動費ベースで考えるのであ

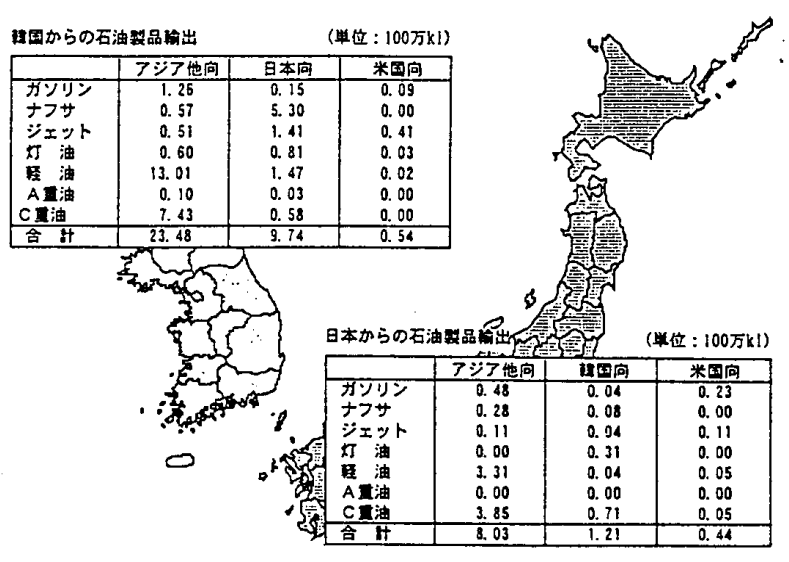

図6 日本および韓国の石油製品輸出の現状 (出所) 石油資料月報、大韓石油協会資料などのデータから作成

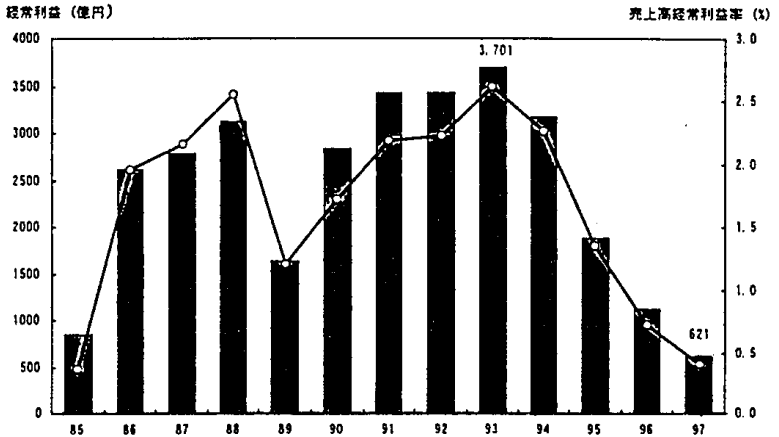

図 4 石油製品価格の下落による日本石油産業の 経常利益の悪化

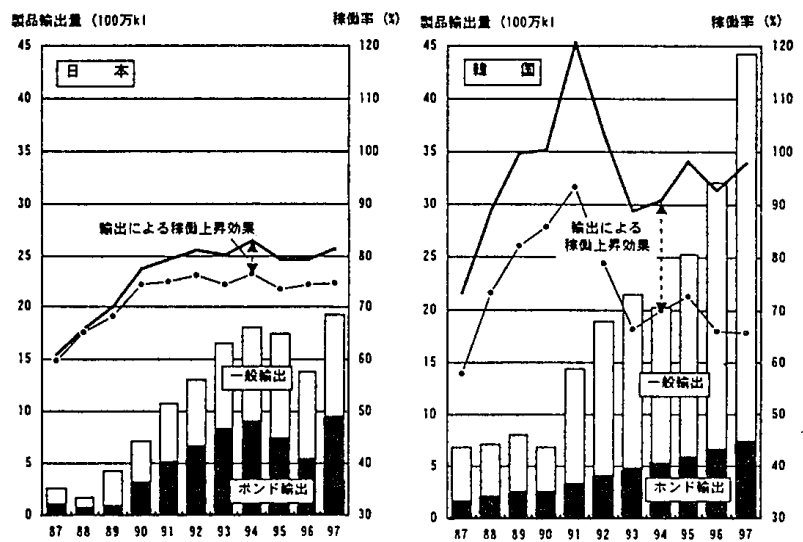

図 5 日韓における石油製品輸出の拡大と製油所稼 働への効果

(出所) 石油資料、平成10年〜 14 年度石油供給計画、大韓石油協会 資料のデータより作成

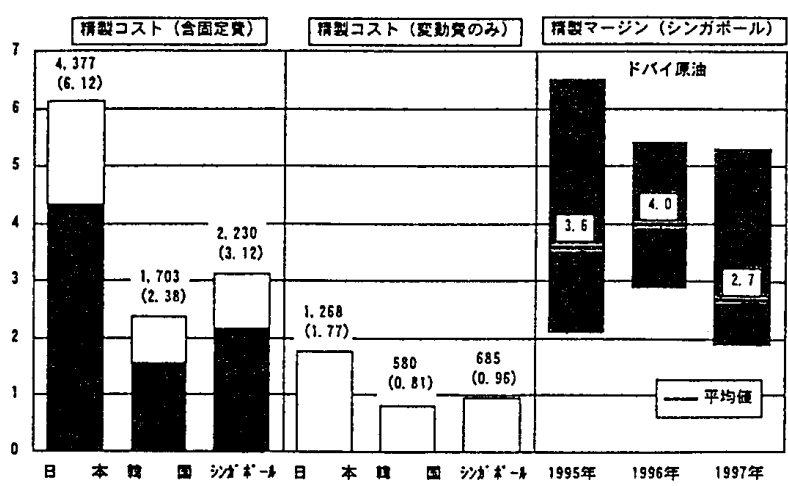

図7 日本、韓国、シンガポールの精製コストの比較

（注） 精製マージンは1992年 1 月から1998年5月までの平均值 と最大値、最小値である。精製コストの数字は、上段が 円/klの值で、下段のカッコ内が\$/Bの值である。

（出所）精製コスト：石油審議会、精製専門委員会のデータから 作成、精製マージン：シンガポールの分解型製油所の典 型的な得率とシンガポール製品市況からネットバック価 值を算出して作成 
れば、わが国の石油製品輸出が競争力を持つ機会は多く、石油製品輸出む一定の収益に奇与できるオプシ ヨンの 1 つとして重要な位置付けを持つようになってきた。

\section{3 日韓提携検討の意義}

わが国の石油産業は、近年国内の企業間の相互融通によって物流合理化を図ってきたが、日韓の蔇設精 製能力の立体的なロケーションを考慮すると、さらに日韓企業間で石油製品の相互融通を図ることむ、相 互に一定の経済的効果を生み出す可能性があると考えられる。

通貨危機が引き起こした課題に直面する韓国の石油産業と規制緩和が引き起こした課題に直面するわが 国の石油産業は、それぞれ相互に補完しあえる可能性む有している。これらの諸点も考慮しつつ、今後の アジア石油市場の将来展開も踏まえると、日韓石油産業の提携オプションの可能性に経済的検討を加えて みることは、大いに必要かつ重要であると判断される。

\section{4.日韓提携オプションの経済性検討}

\section{1 経済性分析のフレームワーク}

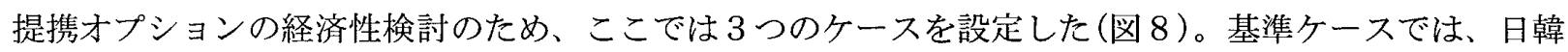
間の石油製品貿易は1997年実績で固定し、両国がそれぞれ単独で製油所の稼働を上げて域外(以下では日韓 域外を意味し、アジアおよび北米西海岸市場を指す)への石油製品輸出を拡大する場合をモデル分析する。 これに対して、日韓提携ケース 1 では、日韓間の相互融通を自由にして両国が域外への石油製品輸出をつ リーに行う場合を分析する。日韓提携ケース 2 では、日韓間の相互融通は自由にするが、日本は輸出活動 がオフサイト(バース、製品タンクなど)制約を受 ける可能性があるので、日本からの域外輸出は 1997年実績を最大と設定して分析する。日韓提携 ケース 2 では、韓国へ転送してそこから域外へ輸 出する場合を分析することとする。

さらに、基準ケースと日韓提携の 2 ケースに対 して、アフリカ原油を調達して中東原油との間で 振り替わりが起こる場合に、日韓間の石油製品の 相互融通あるいは域外輸出にもたらされる効果と その経済性を分析する。アフリカ原油の調達は、 割高感をもって推移する中東原油の価格に影響を 及ぼすことができる有力なオプションである。

この経済性の検討のために、本研究では日韓 8 製油所と 8 需要地および 2 輸出市場(アジアと北 米)からなる石油精製モデルを開発した（図 9)。

本精製モデルでは、日韓の収益最大(プロフィッ トマックス)を目的関数として最適化を行う。収益 (P) は、8 需要地と 2 輸出市場のそれぞれに設定 した各種石油製品の販売価格に基づく売り上げ高 (S) から、【8製油所から10需要地までの各製品 輸送運賃 (T 1)、産油国加ら各製油所までの各種 原油輸送運賃 ( $\mathrm{T} 2$ )、製油所のエネルギーコスト (E)、触媒 - 水道 - 薬品費 $(\mathrm{W})$ 、原油代金 $\mathrm{C}$ (金利、 保険料込み)】を差し引いたもの $(\mathrm{P}=\mathrm{S}-\mathrm{T} 1-\mathrm{T}$ $2-\mathrm{E}-\mathrm{W}-\mathrm{C}$ ) である。

\section{2 経済性検討の前提条件}

日韓提携オプションに関する経済性検討をモデ ル分析で行らために、国内需要、精製設備、原油

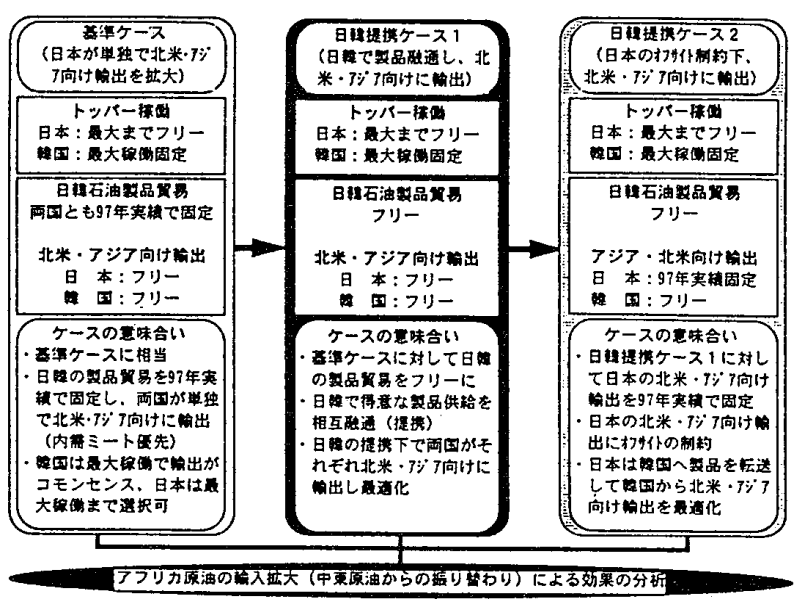

図 8 精製モデルによる日韓提携オプションの経済 性分析のフレームワーク

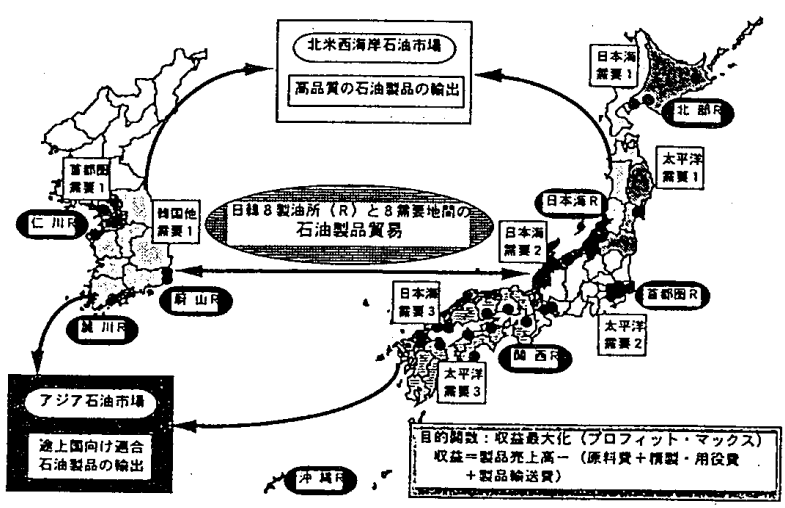

网 9 日韓提携オプションの分析に用いた精製・輸 送モデルの構造 
表 2 日韓提携オプションの分析のために設定したモデルの前提条件

\begin{tabular}{|c|c|}
\hline 項 & 前 提 条 件 $の$ 設 定 内 容 \\
\hline 国内需要 & 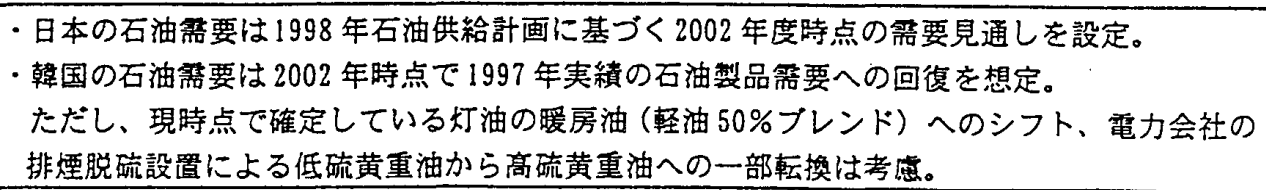 \\
\hline 精彆設併 & 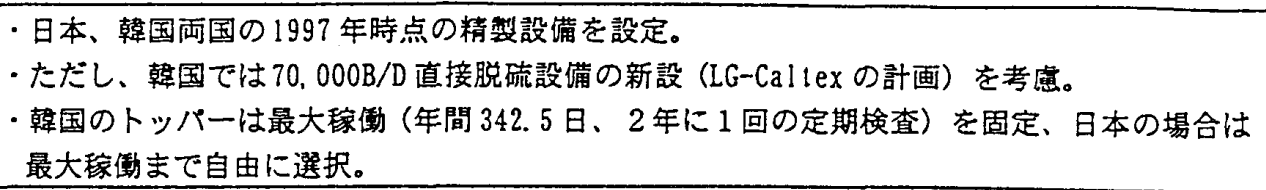 \\
\hline 原油の入手可能性 & 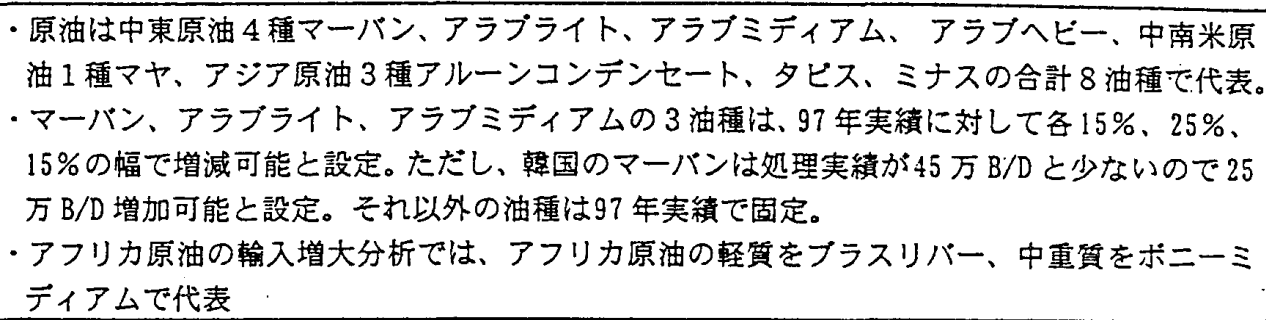 \\
\hline 輸送コスト & 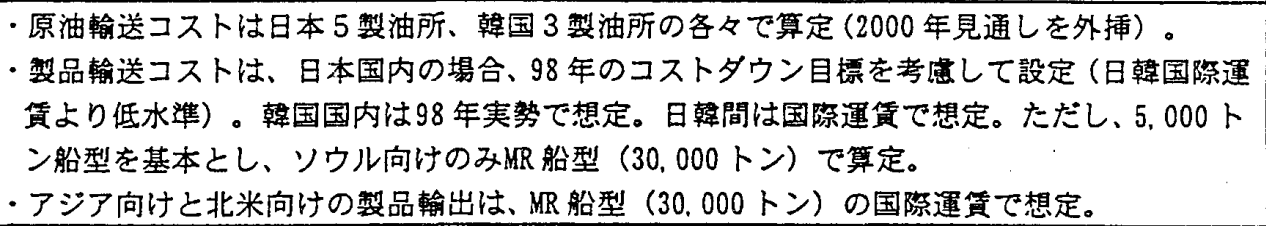 \\
\hline 原油・冓品価格 & $\begin{array}{l}\text { ・原油価格は、97 年長期契約ベースの実績値に、各䌘油所ことの運貨、保険、金利を加算。 } \\
\text { ・慗品価格は、97 年実績のシンガポール国際市況（MOPS）、日本国際市況（MOPJ）、北米西海 } \\
\text { 岸国際市況に基づいて設定。 }\end{array}$ \\
\hline
\end{tabular}

の入手可能性、原油・製品価格、輸送コストなど様々な前提条件の設定を行った。その内容を表に示す(表 2)。

\section{5. 日韓提携オプションの分析}

\section{1 提携による石油製品貿易と設備稼働の変化}

5.1 .1 基準ケース

本ケースでの日韓両国による域外輸出は、日本の 製油所稼働が上昇する結果、約 4,100 万 $\mathrm{k} \ell に$ 達し(図 10）、1997年の域外輸出実績と比較すると 1,000 万 $\mathrm{k} \ell$ 程度の輸出増となる。

基準ケースに対して、2つの提携ケースをみると、 域外輸出の量的な変化はそれほどないが、高品質軽 油の輸出増とHS重油の輸出減を中心に輸出製品の

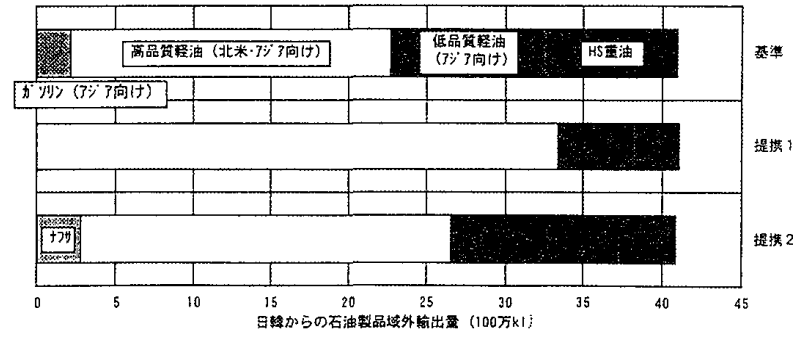

図10提携による日韓から日韓域外への石油製品輸 出の変化 質的な変化がみられる。日韓提携ケース 1 の場合は、

日本側のオフサイト制約を考慮せず、日本からも自由な輸出ができることを前提にしており、日本から域 外への高品質軽油の輸出が大幅に増大することが特徴である(図11)。高効率のトッパーで生産されるジェ ット燃料油とHS重油を韓国から日本へ輸出し、日本の脱硫・分解余力を有効利用することで、高品質軽油 の生産を最大化している。日本から韓国へは、硫黄分規制の強化で需給が苦しくなるLS重油の輸出が行わ れている。

他方、日本側のオフサイト制約を考慮した日韓提携ケース 2 では、日本から韓国へLS重油が輸出される ほかに、大量の樑度脱硫軽油が韓国へ輸出される。そして韓国の強力な輸出インフラストラクチュアを用 いて高品質軽油および途上国向け適合品質軽油を中心とする域外輸出が韓国から行われる。韓国から日本 への輸出は、HS重油に絞られることになる。日韓提携ケース 2 では、日韓提携ケース 1 と比較すると、域 
外輸出製品の高付加 価值度が低下する結 果となっている。

尚、日韓間の貿易 量注年間30～38百万 KL (1997年の2.7〜 3.5倍)へと活発化す る。特に 3 万トンサ イズのジェット・軽 油の物流量が増加す る。今後将来の海運 能力に付いても検討 していく必要があ る。
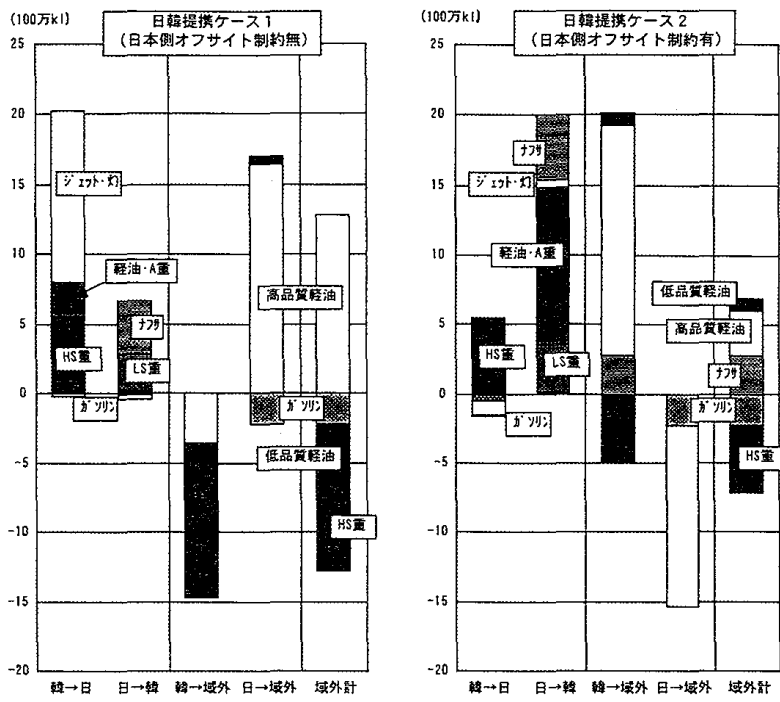

図11提携による日韓の石油製品貿易（相互融通と 域外輸出）の変化要因

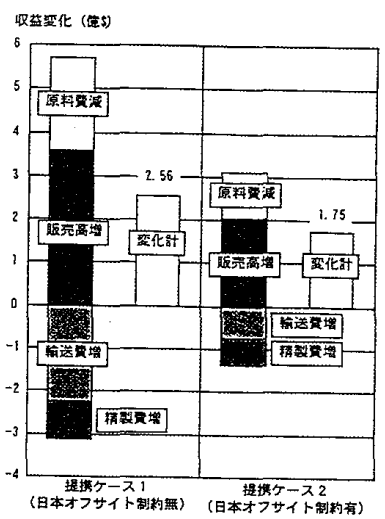

図12 日韓の提携が収益 変化に及ぼす効果

日韓の提携による

脱硫・分解設備の稼働変化をみると、脱硫設備では日本の直接脱硫装置および分解設備では、日本のコー カーの稼働率が上昇しているのが特徴である。韓国では、フル稼働状態が持続している。

5.2 提携による収益(経済性)の変化

日韓が提携した場合の收益の変化を基準ケースからの差としてみると、日韓提携ケース 1 では2.56億ド ルの収益増、日韓提携ケース 2 では1.75億ドルの収益増となる(図12)。脱硫・分解設備の稼働が上昇し、 北米西海岸を中心とする高品質軽油の輸出となるので、精製費、輸送費いずれも増加するが、効率化が図 られて原料費が幾分縮小するとともに、何よりも域外輸出製品の高品質化による販売高の増加が収益に大 きく寄与している。

表 3 日韓提携オプションの経済性の検討に関するまとめ

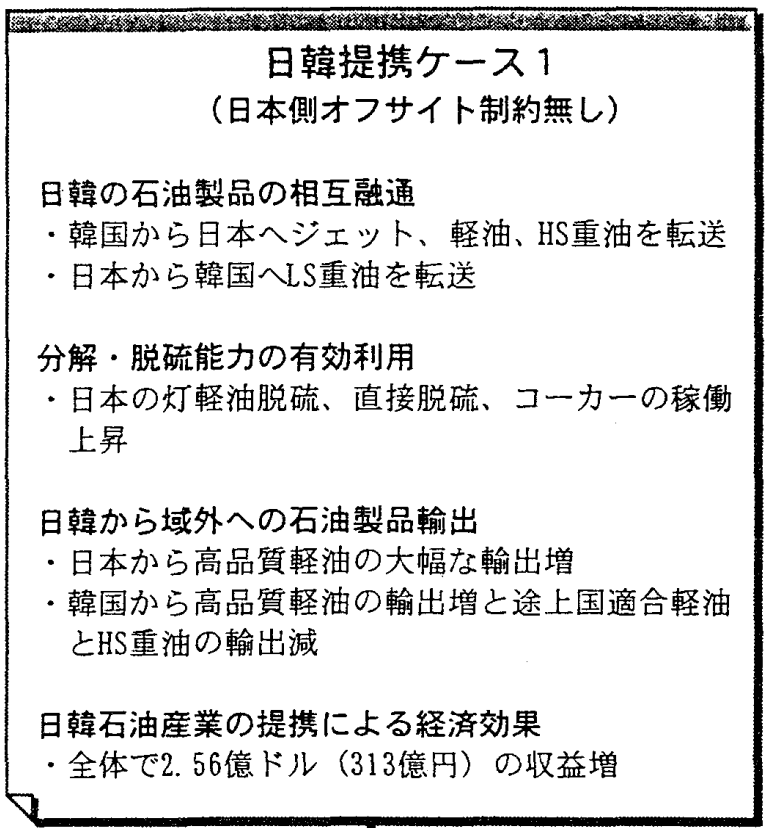

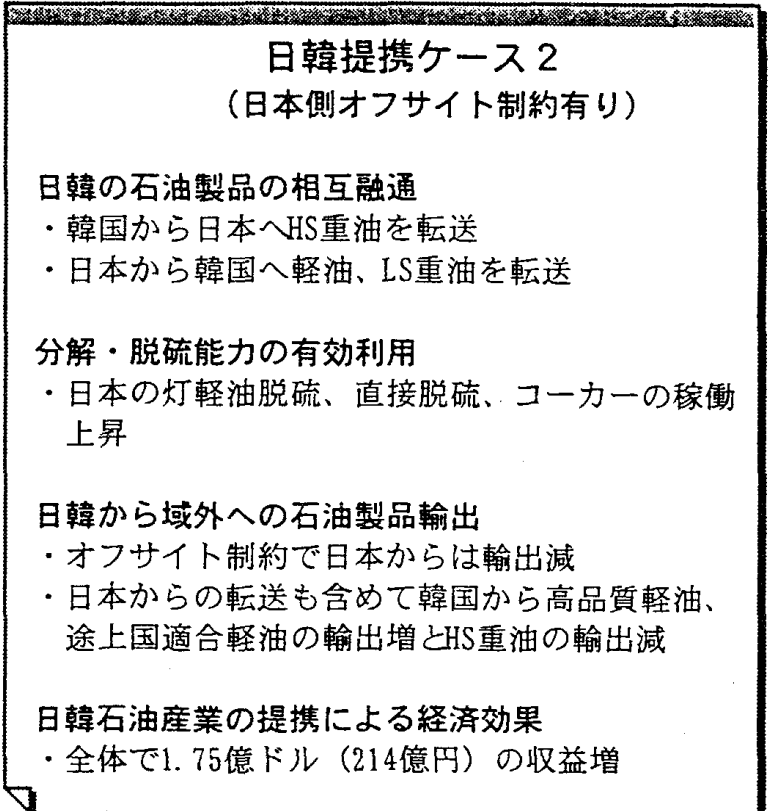


表 4 アフリカ原油調達の経済性の検討に関するまとめ

基準ケース

・日本、韓国いずれもアフリカ原油を調達して脱硫設備の稼働を抑制。分解設備への効果は薄い。

・日韓の製品貿易は97年夷績で固定。域外製品輸出は日本からは変化小。韓国からは高品質軽油、途上国向け 適合軽油の輸出增とHS重油の輸出減。

・全体で1. 57億ドル（192億円）の収益增。

\section{日得提簒ケース 1 （日本側オフサイト制約無し）}

・日本はアフリカ原油よりマーバンヘシフト。韓国はアフリカ原油を最大限調達。

・脱硫設備の稼伤を㧕制。分解設備への効果は薄い。

・日本からのLS重油の転送減少。韓国からのジェット燃料の転送も幾分減少。域外製品輸出は日本からは大 きな変化なし。韓国からは高品質軽油、途上国向け適合軽油の輸出增出S重油の輸出減。

・全体で1.06億ドル（129億円）の収益増。基準ケースより幾分縮小。

\section{日韓提携ケース 2（日本側オフサイト制約有り）}

・日本はアフリカ原油よりマーバンヘシフト。韓国はアフリカ原油を最大限調達。

・脱硫設備の稼働を抑制。分解設備への効果は薄い。

・日本からのLS重油の転送減少。韓国からの転送変化小。域外製品輸出は、日本からは変化なし。韓国から は高品質軽油の輸出增とHS重油の輸出滅。

全体で1.22億ドル（149億円）の収益増。基準ケースより幾分縮小。

アフリカ原油の調達で1.0〜1.6億ドルの収益増加が期待され、輸 出マージンを1 バレル当たり0.4〜0.6ドル改善する効果を持つ

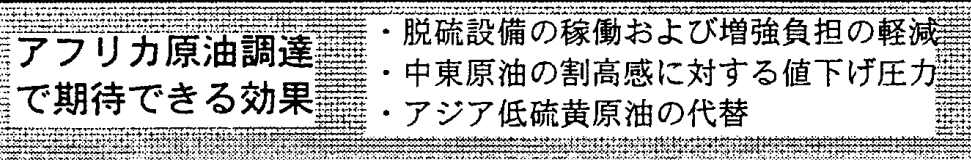

日韓の相互融通による石油製品貿易は、より高効率に両国の内需を充たしつつ域外輸出の付加洒值を更 に増加させる働きを持っている。日韓石油産業の提携によって年間1.7〜2.6億 $\$$ の収益向上が期待される (表 3 )。

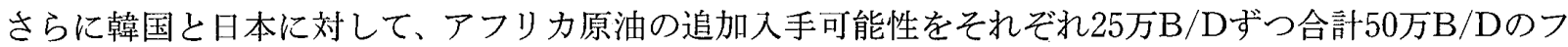
レキシビリティを与えて、中東原油との振り替わりがもたらす効果を分析した(表 4)。

収益変化の合計をみると、各ケースにおいて1.0 1.5億ドル増加する。アフリカ原油の調達は、輸送費 がかかる上に価格面でも中東原油より幾分高いので、原料費負担が増すことになるが、高品質軽油をより 多く域外輸出できるので、販売高もそれを上回って増えることになる。アフリカ原油の調達は、中東原油 の割高感に対する值下げ圧力の効果も期待できるので、重要な位置付けをもつオプションの1つといえる。

\section{6. 日韓提携オプションの具体的な分野と今後の検討課題}

\section{1 具体的な分野}

提携オプションが具体的な可能性を持つ分野として、(1)日韓間の石油製品相互融通、(2)日韓の提携によ る石油製品輸出の拡大と效率化および(3)原油の共同購入、共同輸送等を挙げることができる。

\section{2 今後の検討課題}

これらの提携オプションの実現を図るためには、様々な障害を乗り越えていかなければならない。モデ ル分析では必ずしもみることができなかった障害も数多く存在する。例えば、日韓の民族意識、歴史的な 国民感情、商習慣の違いなども、提携するとなれば乗り越えなければならない壁である。両国の海運規制 および石油製品関税なども提携のためには検討を要する課題となる。

アジア地域の石油製品市場規模は欧州と同程度となり、特に中国の潜在需要 ${ }^{(4)}$ おび先進的公害対策を 
進めている日韓両国を併せ持つ東アジア市場は規模的にも品質的にもアジア地域において、最も重要な地 域となっている。原油タンカーのダブルハル設計・新造船 ${ }^{(5)(6)}$ が進みつつある中で国際的海上物流の革新 (7)も念頭に置きつつ、本市場におけるより高効率な石油製品供給システムを実現し、石油セキュリテイ上の 観点を含む国際競争力を回復(8)(9)・確保する方向での検討・試行が緊急に求められていると考える。

\section{参 考 文 献}

(1) 内航海運日本内航海運組合総連合会編集：「内航海運」平成元年 7 月 20 日発行, pp.26, pp.32，1989.

(2) 日本経済新聞：平成11年 4 月 29 日発行

(1)22面記事「内航タンカー運賃競争激化で先安感」(2)23面論考「グローバリテイーの時代に」ダニエル ヤーギン氏.

（3）三村眞人・小林照夫・富田 功：「貿易と港」成山堂書店平成10年 7 月 28 日発行, p.216, p.232.

(4) 財)日本エネルギー経済研究所エネルギー計量分析センター：「アジアAPEC地域における石油製品の 需給構造ならびに貿易フローに関する動向調査」平成 9 年 3 月発行, p.86-87.

（5）山口勝治・山之内博：二重船款構造モデルタンクよりの油流出一II., 日本航海学会論文集平成 6 年 3 月90号, p.185, 1994.

（6）海事実務研究会編「図説海事概要」海文堂出版株式会社平成 5 年 5 月 10 日発行，p.40.

（7）近藤宏一・賞雅寬而・林 尚吾：北極海航路を航行する原子力商船の経済的可能性, 日本航海学会論 文集平成 9 年 3 月 96 号, p.139, 1997.

(8) 宮本清四郎：「海運産業経済論」海文堂出版株式会社昭和60年 4 月10日発行，p.44.

(9）財)日本エネルギー経済研究所：「石油セキュリテイに関する論点及び石油市場機能に関する調查」平成 10年 3 月発行, (1)p.4-5 (2)p.24. 